\title{
ANALISIS USAHA PARIWISATA DALAM MENGHADAPI RISIKO BENCANA ALAM DI KECAMATAN LEMBANG
}

\author{
Moch Aditya Akbar ${ }^{(1)}$, Fitri Rahmafitria ${ }^{(2)}$, Ghoitsa Rohmah Nurazizah ${ }^{(3)}$ \\ (1), (2), \& (3) Program Studi Manajemen Resort \& Leisure \\ Fakultas Pendidikan Ilmu Pengetahuan Sosial \\ Universitas Pendidikan Indonesia \\ mochadityakbr@gmail.com, rahmafitria@upi.edu, ghoitsa.rohmah@upi.edu
}

Submitted: 13 July 2020 Revised: 29 September 2020

Accepted: 5 October 2020

\begin{abstract}
ABSTRAK
Peluang terjadinya bencana di kawasan wisata alam selalu ada, sehingga ketahanan usaha pariwisata menjadi isu yang penting. Penelitian ini bertujuan untuk mengidentifikasi kesiapan usaha pariwisata khususnya UMKM (Usaha Mikro Kecil Menengah) dalam menghadapi potensi bencana di masa yang akan datang. Empat indikator yang digunakan untuk mengklarifikasi yaitu kesiapan UMKM pariwisata, kesadaran dan pemahaman terhadap potensi bencana, aspek bahaya, dan aspek kerentanan. Pengumpulan data dilakukan dengan wawancara semi-terstruktur dengan pemilik usaha pariwisata yang mencakup bidang usaha akomodasi, pusat oleh-oleh, serta usaha perjalanan wisata. Hasil wawancara diubah menjadi transkrip lalu direduksi menghasilkan kode bentuk kesiapan UMKM pariwisata dalam menghadapi bencana sesuai standar Badan Nasional Penanggulangan Bencana (BNPB) dari skala tinggi hingga rendah. Hasil penelitian menunjukkan bahwa seluruh UMKM mempunyai kesadaran akan potensi bencana pada tingkat sedang. Mayoritas UMKM skala besar memiliki kesiapan yang lebih tinggi, sedangkan UMKM kecil hanya sadar akan adanya potensi bencana. Sementara itu, seluruh UMKM memiliki tingkat kerentanan bencana alam yang tinggi. Secara keseluruhan masih terdapat UMKM baik skala tinggi maupun rendah yang memiliki risiko bencana yang tinggi, sehingga dibutuhkan rencana mitigasi yang melibatkan seluruh stakeholder, melalui koordinasi yang efektif dari pemerintah daerah.
\end{abstract}

Kata Kunci: Kesiapan menghadapi bencana, risiko bencana, usaha pariwisata, wisata alam

\section{TOURISM BUSINESS RISK ANALYSIS IN FACING NATURAL DISASTERS RISK}

\section{ABSTRACT}

This study aims to identify the readiness of tourism businesses, especially MSMEs (Micro, Small and Medium Enterprises) in facing potential natural disasters in the future. The method used in this research is a qualitative approach by using four indicators to analyze the readiness, namely clarification of tourism SMEs, awareness and understanding of potential disasters, aspects of danger, and aspects of vulnerability. Data collection was carried out through semistructured interviews with tourism business owners covering the accommodation business, souvenir centers, and tourist travel businesses. The interview results were changed to the transcript and then reduced to produce a code of tourism MSME readiness in facing disasters according to the National Disaster Management Agency (BNPB) standards from high to low 
scale. Drawing conclusions from the findings states that all MSMEs are aware of potential disasters at a moderate level. The majority of MSMEs with more excellent assets and income have better-planned preparation for dealing with disasters in the future. In comparison, MSMEs that have smaller income levels are only aware of the potential for disasters. For the vulnerability level, tourism SMEs in the District of Lembang has a high vulnerability to disasters. The aspects studied to measure the level of vulnerability are economic, social, and physical aspects. From the disaster's risk level, tourism MSMEs that become the research sample have different results from each MSME classification studied. There are three tourism MSMEs included in the micro, small and medium classification at the high-risk level. For medium risks, there are no MSMEs that are included in this level of risk. There are five tourism MSMEs included in the micro and middle classification for the low-risk level. The suggestion that resulted from this research is a disaster prevention action plan whose plans involve all stakeholders, and their implementation is closely monitored.

Keywords: Disaster risk, disaster mitigation, tourism business, tourism SME

\section{PENDAHULUAN}

Sektor pariwisata sangat rentan terkena dampak bencana alam, apalagi jika dikembangkan pada area alami yang secara fisik rawan bencana alam. Seringkali kawasan wisata dengan daya tarik alami yang tinggi memiliki risiko bencana yang sebanding yang bisa terjadi kapan saja (Rahmafitria \& Misran, 2018). Jika tidak memiliki rencana mitigasi yang baik, sektor pariwisata dapat mengalami pengurangan kunjungan yang berkepanjangan, kerusakan infrastruktur dan citra media yang negatif (Huang \& Min, 2002; Huang, Tseng, \& Petrick, 2007).

Rahmafitria dan Nurazizah (2015:80) berpendapat bahwa masyarakat yang berada pada destinasi wisata alam mengambil kesempatan untuk berpartisipasi dalam pengembangan pariwisata seperti dengan membangun fasilitas penginapan, menyediakan makanan dan minuman untuk wisatawan, dan menjadi pemandu lokal. Menurut Orchiston (2012), sektor usaha yang juga menunjang kegiatan wisata dari berbagai skala usaha seperti Usaha Mikro, Kecil dan Menengah (UMKM), juga memiliki risiko terdampak bencana alam. Banyak UMKM pariwisata yang didirikan di sekitar destinasi wisata yang rawan bencana, karena aspek kemudahan dalam mejaring peluang pasar dari banyaknya kedatangan wisatawan. Akibatnya, UMKM ini dapat menjadi salah satu sektor yang berisiko terdampak bencana alam.

Mitigasi bencana dalam ranah pariwisata sudah menjadi sorotan akademis. Sudah banyak kajian yang berfokus pada dampak bencana (Huan,2004), pemulihan pasca bencana (Huang et al., 2008), kerentanan destinasi wisata (Becken et al., 2013), serta respon dan pemulihan pasca bencana (Ritchie et al., 2008). Sementara penelitian tentang risiko usaha pariwisata, khususnya UMKM, dalam menghadapi bencana masih belum banyak diteliti. Padahal, UMKM pariwisata sangat penting keberadaanya untuk menyokong keberlangsungan kegiatan pariwisata daerah. Baru ditemukan satu kajian yang meneliti tentang kesiapan bencana dari perspektif UMKM pariwisata yang dilakukan di Southern Apls, Selandia Baru (Orchiston, 2012). Hasil kajian menyimpulkan bahwa ukuran suatu usaha menjadi kunci penting dalam menyiapkan ketahanan menghadapi bencana dan perencanaan mitigasi bencana tingkat nasional.

Kesiapan UMKM dalam menghadapi bencana penting dikaji lebih jauh karena masih rendahnya kesadaran sektor UMKM terhadap potensi bencana alam (Orchiston, 2012). Seringkali UMKM dianggap bukan bagian dari manajemen bisnis yang terlibat dalam perencanaan bencana, terutama jika terletak di daerah yang tidak memiliki sejarah 
bencana alam (Prideaux, 2003). Hambatan juga terlihat dari kesadaran UMKM pariwisata yang masih sangat minim terhadap ancaman bencana di masa depan. Ritchie, Bentley, Koruth \& Wang (2011) menjelaskan bahwa pengelola UMKM enggan mengambil respon strategis dalam manajemen bencana. Mereka lebih memilih pendekatan reaksioner daripada perencanaan yang terperinci. Di sisi lain, buruknya tingkat perencanaan bencana kemungkinan disebabkan oleh kurangnya kesadaran akan metode perencanaan bencana dan kurangnya sumberdaya dalam bisnis skala kecil (Drabek, 1994, 1995; Hystad \& Keller, 2006; Webb, Tierney, \& Dahlhamer, 2002).

Sehubungan dengan hal tersebut, banyak aspek yang harus diperhatikan untuk mengetahui bagaimana risiko UMKM Pariwisata dalam menghadapi bencana alam yang akan terjadi. Perspektif mitigasi bencana dapat digunakan untuk menganalisis tingkat kesiapan dan risiko bencana. Karena dalam mitigasi bencana terdapat kajian risiko bencana yang dibuat dengan tujuan untuk mengurangi risiko bencana yang akan terjadi (Prideaux, 2003).

Penelitian ini bertujuan untuk menganalisis tingkat risiko dan kesiapan berbagai level UMKM pariwisata dalam menghadapi bencana alam yang akan terjadi. Apakah level UMKM yang berbeda berdampak pada tingkat risiko bencana dan kesiapannya dalam menghadapi bencana? Karena secara teoretis, semakin tinggi level UMKM, maka tingkat risikonya pun akan makin tinggi dan mendorong upaya mitigasi yang semakin baik.

Penelitian dilakukan di kawasan sesar Lembang, Kabupaten Bandung, yang merupakan kawasan wisata pegunungan yang popular di Jawa Barat. Menurut Meilano (2017), kawasan ini memiliki potensi gempa bumi sebagai akibat pergerakan sesar dan letusan gunung api. Kawasan ini menjadi wilayah studi yang tepat karena banyaknya UMKM wisata yang mengembangkan usahanya di kawasan Lembang dan peningkatan jumlah kunjungan wisatawan (Gatra, 2019). Secara umum, hasil penelitian ini dapat menjadi masukan bagi stakeholder pariwisata yang beroperasi di wilayah rawan bencana untuk mempersiapkan upaya mitigasi dalam mengurangi risiko bencana yang semakin tinggi.

\section{TINJAUAN PUSTAKA Mitigasi Bencana di kawasan wisata}

Kesiapan destinasi wisata tidak hanya dilihat dari fasilitas dan infrastruktur untuk kegiatan wisata saja, tetapi juga dilihat dari aspek keselamatan dan keamanan berwisata, termasuk sistem mitigasi kerawanan yang ada di destinasi tersebut (Rahmafitria \& Misran, 2018). Upaya preventif dalam pengurangan risiko bencana untuk mengurangi dampak yang ditimbulkan merupakan strategi yang penting. Mitigasi bencana adalah serangkaian upaya untuk mengurangi risiko bencana, baik melalui pembangunan fisik maupun penyadaran dan peningkatan kemampuan menghadapi ancaman bencana (PP No. 21 Tahun 2008). Beberapa peneliti menjelaskan bahwa salah satu masalah dalam mitigasi bencana alam di kawasan wisata adalah tidak adanya program yang terencana dan komprehensif yang dipahami oleh semua stakeholder, termasuk sektor usaha (Faulkner, 2001). Yuliani, Kastolani \& Rahmafitria (2018:61) menjelaskan tujuan utama dari Mitigasi Bencana adalah untuk 1) Mengurangi risiko/dampak yang ditimbulkan oleh bencana seperti korban jiwa (kematian), kerugian ekonomi (economy costs) dan kerusakan sumber daya alam. 2) Sebagai landasan (pedoman) untuk perencanaan pembangunan. 3) Meningkatkan pengetahuan masyarakat (public awareness) dalam menghadapi serta mengurangi dampak/risiko bencana, sehingga masyarakat dapat hidup dan bekerja dengan aman.

\section{Kesiapan UMKM dalam menghadapi bencana}

Analisis yang dikumpulkan oleh auditor KPMG India (2016) dari UMKM yang dijadikan sampel penelitian mengungkapkan bahwa adanya kekurangan persiapan dan 
pemulihan pasca bencana yang bisa dilihat dari beberapa aspek berikut:

Rencana Pemulihan Bisnis, Karena sifat informal yang dijalankan beberapa UMKM menyebabkan tidak adanya dokumen yang disusun secara formal terkait rencana pemulihan bisnis dalam menghadapi bencana. Padahal, dokumen ini berguna dan berfungsi untuk mengidentifikasi kemungkinan terjadinya suatu bencana, kegiatan yang harus dilakukan sebelum dan sesudah bencana, serta cara mengurangi dampak dan melanjutkan kegiatan bisnis secepatnya.

Kunci utama dari Rencana Pemulihan Bisnis terdapat pada kesiapan staf atau karyawan dalam menanggulangi suatu bencana. Namun, banyak dari UMKM tidak mempunyai staf yang waspada dan terlatih untuk menghadapi bencana. Selain itu, mereka juga tidak menyiapkan peralatan darurat di tempat mereka.

Kendala Lokasi, Beberapa UMKM tidak memperhatikan lokasi tempat mereka membuka usaha.

Asuransi yang tidak mencukupi, Cover asuransi merupakan salah satu pilar penting untuk membantu pemulihan suatu UMKM. Banyak pemilik UMKM yang memandang asuransi sebagai pengeluaran daripada suatu investasi. Padahal, kebijakan pihak asuransi bisa membantu UMKM untuk cepat berpoperasi kembali pasca bencana.

Dukungan Perbankan, Dukungan perbankan yang tidak memadai dalam hal keringanan pinjaman, memperpanjang periode pinjaman, menambah modal kerja, batasan jangka waktu pinjaman, memberikan moratorium adalah beberapa langkah yang perlu dipertimbangkan oleh bank. Saat ini belum ada pedoman rekomendasi bagaimana hubungan antara bank dan pengusaha saat terjadinya bencana.

\section{METODE PENELITIAN}

Metode dan pendekatan dalam penelitian penelitian ini adalah deskriptif kualitatif. Dengan menggunakan pendekatan kualitatif, peneliti dapat menemukan sejauh mana kesiapan UMKM pariwisata di kecamatan Lembang dalam menghadapi bencana.

Pengumpulan data dilakukan dengan wawancara pada 8 pemilik UMKM, yang terdiri dari 2 UKM skala mikro, 4 UMKM skala menengah dan 2 UMKM skala kecil. Tahapan teknik pengolahan data yang dilakukan adalah pertama menganalisis data dengan verbatim, yaitu mentranskrip data atau membuatnya menjadi teks naratif. Menurut Miles dan Huberman (1984), bentuk yang paling sering digunakan dari model data kualitatif selama ini adalah teks naratif. Semua data yang telah diambil selama proses wawancara ditranskrip dan diidentifikasi sesuai dengan aspek-aspek penilaian dari hasil transkrip. Tahap selanjutnya, peneliti menggunakan sistem analisis konten untuk mengevaluasi klasifikasi UMKM dan menganalisis hasil respon kesiapan UMKM dalam menghadapi bencana.

Sementara variabel penelitian untuk analisis ini menggunakan beberapa rujukan, yaitu klasifikasi UMKM (UU nomor 20 tahun 2008), analisis kerentanan bencana (BNPB, 2015) dan kesadaran terhadap bencana (Johnston, Bebbington, Lai, Houghton, \& Paton, 1999). Adapun variabel yang diteliti sebagaimana Tabel 1 berikut:

Tabel 1. Variabel Penelitian

\begin{tabular}{|c|c|c|c|}
\hline Variabel & Instrumen & Parameter & $\begin{array}{l}\text { Sum- } \\
\text { ber } \\
\text { refe- } \\
\text { rensi }\end{array}$ \\
\hline $\begin{array}{l}\text { Klasifikasi } \\
\text { UMKM } \\
\text { Pariwisata }\end{array}$ & $\begin{array}{l}\text { Kriteria } \\
\text { UMKM } \\
\text { menurut UU } \\
\text { nomor } 20 \\
\text { tahun } 2008\end{array}$ & $\begin{array}{l}\text { - Jumlah Kekayaan } \\
\text { UMKM } \\
\text { - Jumlah } \\
\text { Penghasilan } \\
\text { UMKM }\end{array}$ & $\begin{array}{l}\text { UU } \\
\text { nomor } \\
20 \\
\text { tahun } \\
2008\end{array}$ \\
\hline $\begin{array}{l}\text { Kesadaran } \\
\text { Potensi } \\
\text { Bencana }\end{array}$ & $\begin{array}{l}\text { Kesadaran } \\
\text { UMKM } \\
\text { Pariwisata } \\
\text { terhadap } \\
\text { potensi } \\
\text { bencana }\end{array}$ & $\begin{array}{l}\text { - Kesadaran bencana } \\
\text { - Pemahaman } \\
\text { potensi bencana }\end{array}$ & $\begin{array}{l}\text { (Johns } \\
\text { ton, } \\
\text { Bebbi } \\
\text { ngton, } \\
\text { Lai, } \\
\text { Hough } \\
\text { ton, \& } \\
\text { Paton, } \\
\text { 1999) }\end{array}$ \\
\hline $\begin{array}{l}\text { Aspek } \\
\text { Bahaya }\end{array}$ & $\begin{array}{l}\text { Lokasi } \\
\text { UMKM } \\
\text { Pariwisata }\end{array}$ & $\begin{array}{l}\text { Lokasi UMKM } \\
\text { pada Kawasan } \\
\text { Rawan Bencana }\end{array}$ & $\begin{array}{l}\text { BNPB } \\
\text { (2015) }\end{array}$ \\
\hline $\begin{array}{l}\text { Aspek } \\
\text { Kerentanan }\end{array}$ & $\begin{array}{l}\text { Kerentanan } \\
\text { Fisik } \\
\text { UMKM }\end{array}$ & Nilai Bangunan & $\begin{array}{l}\text { BNPB } \\
(2015)\end{array}$ \\
\hline
\end{tabular}


Moch Aditya Akbar, Fitri Rahmafitria, dan Ghoitsa Rohmah Nurazizah: Analisis Usaha

Pariwisata Dalam Menghadapi Risiko Bencana Alam di Kecamatan Lembang

\begin{tabular}{lll}
\hline Pariwisata & & \\
Keretanan & - Aset Perusahaan & BNPB \\
Ekonomi & - Pendapatan & (2015) \\
Pariwisata & Perusahaan & \\
\hline Kerentanan & Kompleksitas & BNPB \\
Lingkungan & Perusahaan & $(2015)$ \\
UMKM & & \\
Pariwisata & & \\
\hline Kerentanan & Usia, jenis kelamin, & BNPB \\
Sosial & Gender, tingkat & (2015) \\
UMKM & pendidikan & \\
Pariwisata & karyawan UMKM & \\
\hline
\end{tabular}

Sumber : Hasil Olah Data, 2019

Dalam penelitian ini, penyajian data dilakukan dengan membuat tabulasi dari teks naratif yang diuraikan beserta bagan, foto atau gambar sebagai pelengkap dari hasil temuan dalam wawancara terhadap narasumber yang terkait. Semua data yang telah ditranskrip lalu diidentifikasi sesuai dengan aspek-aspek penilaian dari hasil transkrip tersebut.

Pada tahap reduksi data, hal-hal pokok dipilah, dirangkum, dan disederhanakan sesuai dengan data yang berkaitan dan dibutuhkan dalam penelitian. Kemudian, data dibuat menjadi matriks analisis data untuk mencari kode tingkat risiko UMKM yang berasal dari pertanyaan mengenai risiko UMKM dalam menghadapi bencana di kecamatan Lembang.

Langkah selanjutnya yaitu mengkonversi kode tingkat risiko UMKM ke dalam bentuk angka dengan metode skala likert, yaitu metode pengukuran yang mengukur sikap, pendapat dan presepsi seseorang atau kelompok tentang fenomena sosial (Sugiyono, 2012).

Skor kriterium minimal yang dihasilkan dari perhitungan skala likert 8 sementara skor kriterium maksimal bernilai 24. Interval yang digunakan untuk mengukur rating scale bernilai 5.3. Hasil dari perhitungan interval tersebut menjadi rating scale untuk menentukan tingkat kesadaran, kerentanan (sosial, fisik, ekonomi, lingkungan), dan tingkat bahaya UMKM pariwisata (Tabel 2).

Untuk memudahkan proses analisis, peneliti membagi coding tingkat kesadaran bencana menjadi tiga bagian yaitu "rendah", "sedang", dan "tinggi". Pada tingkat "rendah", UMKM pariwisata hanya menyadari akan adanya potensi bencana di masa depan. Untuk tingkat "sedang", UMKM pariwisata tidak hanya menyadari potensi bencana, tetapi juga disertai dengan prosedur mitigasi bencana. Sedangkan untuk UMKM pariwisata dengan tingkat kesadaran "tinggi" diukur dengan adanya kesadaran akan potensi bencana, prosedur mitigasi bencana, serta sumber daya yang mendukung seperti staf yang telah dilatih khusus untuk menanggulangi kejadian bencana dan bangunan yang dirancang khusus dalam menghadapi bencana.

\section{Tabel 2. Skoring penilaian UMKM Pariwisata}

\begin{tabular}{|c|c|c|c|}
\hline \multicolumn{4}{|c|}{$\begin{array}{l}\text { Standar penilaian tingkat kesadaran UMKM } \\
\text { Pariwisata }\end{array}$} \\
\hline Skor & $\begin{array}{l}\text { Rating } \\
\text { scale }\end{array}$ & Keterangan & Nilai \\
\hline Tinggi & $8-13.3$ & $\begin{array}{l}\text { Sadar Bencana, } \\
\text { Mempunyai Prosedur } \\
\text { Mitigasi, Bangunan } \\
\text { tahan bencana, staff } \\
\text { terlatih }\end{array}$ & 3 \\
\hline Sedang & $\begin{array}{l}13.4- \\
18.6\end{array}$ & $\begin{array}{l}\text { Sadar Bencana, } \\
\text { Mempunyai Prosedur } \\
\text { mitigasi }\end{array}$ & 2 \\
\hline Rendah & $18.7-24$ & $\begin{array}{l}\text { Sadar Bencana, } \\
\text { Tidak Mempunyai } \\
\text { Prosedur Mitigasi } \\
\text { Bencana, Tidak } \\
\text { Mempunyai } \\
\text { Bangunan Tahan } \\
\text { Bencana }\end{array}$ & 1 \\
\hline \multicolumn{2}{|c|}{$\begin{array}{l}\text { Standar penilaian } \\
\text { UMKM Pariwisata }\end{array}$} & tingkat kerentanan & sosial \\
\hline Skor & $\begin{array}{l}\text { Rating } \\
\text { scale }\end{array}$ & Keterangan & Nilai \\
\hline Tinggi & $8-13.3$ & $>10$ orang & 3 \\
\hline Sedang & $\begin{array}{l}13.4- \\
18.6\end{array}$ & 5 sd 10 orang & 2 \\
\hline Rendah & $\begin{array}{l}18.7- \\
24\end{array}$ & $<5$ orang & 1 \\
\hline \multicolumn{4}{|c|}{$\begin{array}{l}\text { Standar penilaian tingkat kerentanan fisik UMKM } \\
\text { Pariwisata }\end{array}$} \\
\hline Skor & $\begin{array}{l}\text { Rating } \\
\text { Scale }\end{array}$ & Keterangan & Nilai \\
\hline Tinggi & $8-13.3$ & $>$ Rp. 800 Juta & 3 \\
\hline Sedang & $\begin{array}{l}13.4 \\
18.6\end{array}$ & $\begin{array}{l}\text { Rp. } 400 \text { sd Rp. } 800 \\
\text { juta }\end{array}$ & 2 \\
\hline Rendah & $18.7-24$ & $<\mathrm{Rp}, 400$ juta & 1 \\
\hline \multicolumn{4}{|c|}{$\begin{array}{l}\text { Standar penilaian tingkat kerentanan ekonomi } \\
\text { UMKM Pariwisata }\end{array}$} \\
\hline $\begin{array}{l}\text { Skor } \\
\text { Kapasitas }\end{array}$ & $\begin{array}{l}\text { Rating } \\
\text { Scale }\end{array}$ & Keterangan & Nilai \\
\hline
\end{tabular}




\begin{tabular}{|c|c|c|c|}
\hline Tinggi & $8-13.3$ & > Rp. 200 juta & 3 \\
\hline Sedang & $\begin{array}{ll}13.4 & - \\
18.6 & -\end{array}-$ & Rp. 50 sd Rp. 200 juta & 2 \\
\hline Rendah & $18.7-24$ & < Rp. 200 Juta & 1 \\
\hline \multicolumn{4}{|c|}{$\begin{array}{l}\text { Standar penilaian tingkat kerentanan lingkungan } \\
\text { UMKM Pariwisata }\end{array}$} \\
\hline $\begin{array}{l}\text { Skor } \\
\text { Kapasitas }\end{array}$ & $\begin{array}{c}\text { Rating } \\
\text { Scale }\end{array}$ & Keterangan & Nilai \\
\hline Tinggi & $8-13.3$ & $\begin{array}{l}\text { Wilayah Hutan } \\
\text { lindung dan Hutan } \\
\text { Alam }>75 \mathrm{Ha}\end{array}$ & 3 \\
\hline Sedang & $\begin{array}{ll}13.4 \\
18.6\end{array}$ & $\begin{array}{l}\text { Wilayah Hutan } \\
\text { lindung dan Hutan } \\
\text { Alam 20-75 Ha }\end{array}$ & 2 \\
\hline Rendah & $18.7-24$ & $\begin{array}{l}\text { Wilayah Hutan } \\
\text { lindung dan Hutan } \\
\text { Alam }<20 \mathrm{Ha}\end{array}$ & 1 \\
\hline $\begin{array}{l}\text { Standar } \\
\text { Pariwisata }\end{array}$ & penilaian & tingkat bahaya & MKM \\
\hline $\begin{array}{l}\text { Skor } \\
\text { Kapasitas }\end{array}$ & $\begin{array}{c}\text { Rating } \\
\text { Scale }\end{array}$ & Keterangan & Nilai \\
\hline Tinggi & $0.3-3.2$ & $\begin{array}{l}\text { Berada pada Zona } \\
\text { KRB } 3\end{array}$ & 3 \\
\hline Sedang & $\begin{array}{c}3.3- \\
6.2 \\
\end{array}$ & $\begin{array}{l}\text { Berada pada Zona } \\
\text { KRB } 2\end{array}$ & 2 \\
\hline Rendah & $6.3-9.2$ & $\begin{array}{l}\text { Berada pada Zona } \\
\text { KRB } 1\end{array}$ & 1 \\
\hline
\end{tabular}

Sumber : Risiko Bencana Indonesia, 2016

\section{HASIL DAN PEMBAHASAN}

\section{Kesadaran UMKM pariwisata terkait potensi bencana di Kecamatan Lembang}

Hasil wawancara dan observasi menunjukkan bahwa 8 UMKM pariwisata di Kecamatan Lembang mengetahui adanya potensi bencana yang akan terjadi. Namun demikian, hanya beberapa UMKM yang mempunyai tindakan preventif untuk meminimalisir kerusakan yang terjadi pasca bencana. UMKM mempunyai deskripsi tingkat kesadaran potensi bencana yang berbeda-beda dan cenderung bersikap reaktif pasca bencana, walaupun setiap UMKM pariwisata di Kecamatan Lembang mengetahui adanya potensi bencana alam di wilayah mereka.

UMKM Pariwisata Mikro, dari dua narasumber yang diteliti menujukkan hasil yang berbeda, yaitu memiliki tingkat kesadaran "sedang" dan "tinggi". Hasil yang berbeda disebabkan karena UMKM tersebut mempunyai tingkat penghasilan yang berbeda. Untuk UMKM Mikro dengan tingkat kesadaran "sedang", mereka sudah sadar bencana dan mengetahui adanya prosedur mitigasi bencana meskipun baru sebatas pemaparan apa yang harus dilakukan ketika terjadinya bencana. Sedangkan untuk UMKM Mikro dengan tingkat kesadaran "tinggi", mereka menyadari akan adanya potensi bencana yang terjadi disertai dengan upaya untuk meminimalisir risiko dan kerusakan pasca bencana dengan adanya prosedur mitigasi, staff yang terlatih serta bangunan yang dirancang untuk tahan gempa. Dalam lingkup usaha mikro, hal ini bertolak belakang dengan teori Hystad dan Keller (2008) yang menerangkan bahwa usaha yang lebih besar lebih cenderung mempunyai perencanaan bencana daripada usaha yang lebih kecil. Karena nyatanya di lapangan beberapa UMKM mikro pun nemiliki perencanaan bencana yang baik.

UMKM Pariwisata Kecil, dari tiga narasumber yang diteliti menunjukan hasil yang sama yaitu "rendah". Tiga UMKM tersebut hanya mengetahui adanya potesi bencana tanpa adanya tindakan pencegahan serta tindakan pasca bencana. Menurut Ritchie, Bentley, Koruth, dan Wang (2011), manajer suatu usaha enggan untuk mengambil respon yang lebih strategis terhadap manajemen krisis bencana dan lebih memilih pendekatan reaksioner daripada perencanaan preskriptif yang terperinci. Sesuai dengan pernyataan tersebut, untuk UMKM tingkat kecil, mereka tidak mempunyai persiapan serta perencanaan dalam menghadapi bencana, mereka akan cenderung bertindak reaktif jika terjadi bencana.

UMKM Pariwisata Menengah, dari tiga narasumber yang diteliti, menunjukkan hasil yang sama yaitu "tinggi" karena mereka mempunyai kesadaran bencana yang disertai dengan adanya prosedur mitgasi bencana disertai tindakan untuk meminimalisir risiko dan kerusakan pasca bencana, seperti bangunan yang tahan bencana, staff khusus yang terlatih untuk menghadapi bencana, dan tanda untuk memudahkan proses evakuasi wisatawan. Dalam lingkup UMKM menengah, teori Hystad dan Keller (2008) sesuai dengan dengan keadaan di lapangan karena ketiga sampel tersebut memiliki usaha 
dan penghasilan yang lebih besar dibanding UMKM yang lainnya. Di sisi lain, mereka pun memiliki gedung, bangunan serta aset yang bernilai tinggi sehingga mereka cenderung untuk lebih mempersiapkan perencanaan bencana. Dari hasil analisis yang menggunakan metode likert, hasil penelitian di atas menunjukkan bahwa UMKM pariwisata di Lembang secara kesuluruhan memiliki kesadaran yang "sedang" terhadap potensi bencana. Hasil ini diperkuat oleh teori Prideaux (2003) yang memaparkan bahwa operator pariwisata tidak menganggap perencanaan bencana untuk menjadi bagian penting dari manajemen bisnis, terutama di daerah yang tidak memiliki sejarah bencana alam terkini. Hal ini ditemukan pada beberapa klasifikasi UMKM pariwisata yang berada di kecamatan Lembang. Lembang memiliki potensi bencana gempa sesar lembang yang akan terjadi di masa yang akan datang hanya saja fenomena gempa sesar lembang yang terakhir kali terjadi (Tirto, 2017) bermagnitudo rendah dan tidak terlalu di ekspos media, sehingga UMKM pariwisata pun seolah-olah tidak menganggap gempa sesar lembang sebagai potensi bencana. Dari segi potensi erupsi gunung Tangkuban Parahu pun UMKM pariwisata di kecamatan Lembang tidak mempunyai prosedur mitigasi khusus yang disiapkan jika erupsi terjadi.

\section{Kerentanan UMKM Pariwisata Kecamatan Lembang}

Kerentanan dilihat dari aspek sosial, fisik, ekonomi, dan lingkungan. Kerentanan sosial diindikasikan dari jumlah sumberdaya manusia yang bergantung pada UMKM tersebut, sedangkan kerentanan fisik dilihat dari nilai ekonomi asset yang dimiliki UMKM, kerentanan ekonomi dilihat dari pendapatan, sementara kerentanan lingkungan dilihat kedekatan dan fungsi lindung dimana UMKM tersebut berdiri.

UMKM di kecamatan Lembang memiliki tingkat risiko kerentanan sosial yang "tinggi". Klasifikasi UMKM yang termasuk dalam kategori tinggi mencakup Usaha Mikro, Kecil dan Menengah yang terdiri dari hotel dan usaha oleh-oleh. Mayoritas UMKM memiliki karyawan lebih dari 10 orang. Sementara UMKM lainnya memiliki tingkat kerentanan sosial "rendah" karena memiliki karyawan kurang dari 5 orang dengan klasifikasi usaha mikro berupa usaha perjalanan wisata. Temuan kerentanan fisik terhadap UMKM pariwisata di Kecamatan Lembang menunjukkan bahwa secara kesuluruhan memiliki kerentanan fisik yang tinggi terhadap potensi bencana. Tujuh dari delapan sampel UMKM pariwisata di kecamatan Lembang memiliki aset lebih dari Rp. 800 juta rupiah. Hal tersebut mengakibatkan sangat rentan mengalami kerusakan, bahkan kehilangan nilai aset serta aset fisik jika terjadi bencana di masa yang akan datang. Sementara untuk UMKM lainnya memiliki tingkat "rendah" karena memiliki aset kurang dari Rp. 400 Juta.

Dari segi kerentanan ekonomi, pendapatan UMKM yang menjadi sampel dari penelitian untuk mengukur tingkat kerentanan ekonomi berada pada kisaran Rp.144 Juta Rp.12 Miliar. Hal tersebut terdiri dari UMKM yang menyediakan jasa tour travel, jasa akomodasi, dan sentra oleh-oleh. Hasilnya menunjukkan bahwa UMKM pariwisata di Lembang secara kesuluruhan memiliki kerentanan ekonomi yang "tinggi" terhadap potensi bencana. Tujuh dari delapan sampel UMKM pariwisata di kecamatan Lembang memiliki penghasilan pertahun lebih dari Rp. 200 juta rupiah. Hal tersebut menyebabkan sangat rentan mengalami kerusakan, bahkan kehilangan potensi ekonomi jika terjadi bencana di masa yang akan datang. Sedangkan untuk UMKM lainnya memiliki tingkat "rendah", karena memiliki penghasilan pertahun kurang dari Rp. 50 Juta. Semantara untuk kerentanan lingkungan, jika merujuk pada Perka BNPN No.2 tahun 2012, kerentanan lingkungan diukur dengan parameter hutan lindung, hutan alam, hutan bakau, semak belukar, dan rawa. Hanya saja 8 UMKM pariwisata di Kecamatan Lembang yang menjadi narasumber tidak ada satu pun yang berada pada kawasan dalam parameter tersebut. 
Moch Aditya Akbar, Fitri Rahmafitria, dan Ghoitsa Rohmah Nurazizah: Analisis Usaha

Pariwisata Dalam Menghadapi Risiko Bencana Alam di Kecamatan Lembang

\section{Risiko UMKM Pariwisata Terhadap Erupsi Bencana Gunung Api}

Untuk mengukur tingkat risiko UMKM pariwisata, diperlukan adanya data mengenai tingkat Hazard dalam suatu wilayah. Data yang digunakan dalam penelitian ini merujuk pada Zona Kerawanan Bencana Gunung Api BNPB dengan cara skoring menggunakan metode likert. Hazard dalam kajian ini berasal dari Zona Kerawanan Bencana (KRB) yang digunakan untuk gunungapi. Pada tingkat "Tinggi" UMKM pariwsata berada pada Zona KRB 3. Untuk tingkat "sedang", UMKM pariwisata berada pada Zona KRB 2, sedangkan untuk tingkat "rendah", UMKM pariwisata berada pada Zona KRB 1 .

Dari hasil analisis dengan metode likert menunjukkan bahwa semua UMKM pariwisata di Kecamatan Lembang yang menjadi objek penelitian berada pada tingkat "rendah" yang berarti semua UMKM pariwisata berada pada zoba KRB I, yaitu kawasan yang berpotensi terlanda lahar/banjir dan tidak menutup kemungkinan dapat terkena perluasan awan panas dan aliran lava, selama letusan membesar, kawasan ini berpotensi tertimpa material jatuhan berupa hujan abu lebat dan lontaran batu (BNPB, 2015). Matriks didasari rumus kajian risiko bencana yaitu Risiko = Bahaya $\mathrm{x}$ Kerentanan / Kapasitas. Aspek bahaya dalam kajian ini berasal dari Zona Kerawanan Bencana (KRB) yang digunakan untuk gunung api. Dari hasil analisis menunjukkan bahwa semua UMKM pariwisata yang menjadi objek penelitian berada di KRB I dengan nilai 8 (rendah).

Gambar 1. Peta Lokasi Sampel UMKM

Pariwisata Di Kecamatan Lembang pada Zona KRB

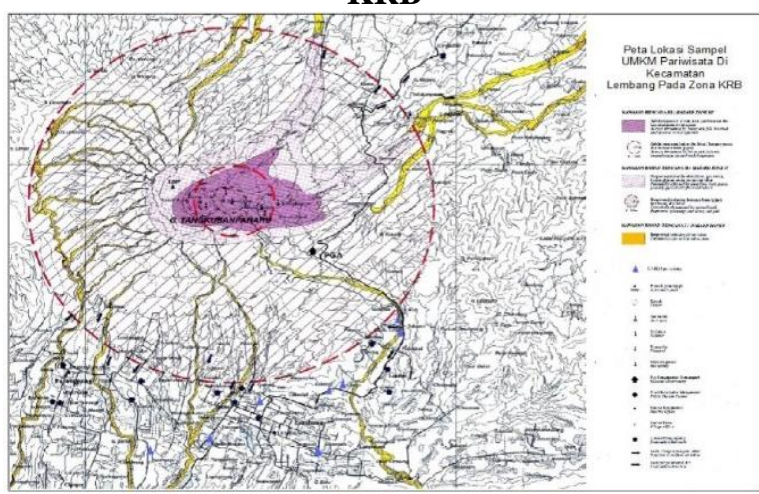

Sumber: Hasil Olah Data, 2019
Dari segi kerentanan, aspek yang digunakan yaitu aspek ekonomi, fisik, dan sosial. Aspek lingkungan tidak disertakan, karena semua UMKM pariwisata dalam Kecamatan Lembang tidak berada pada zona hutan lindung. Selain itu, tiga aspek yang digunakan berguna untuk menyesuaikan penelitian dengan lingkup UMKM pariwisata. Setiap klasifikasi UMKM pariwisata dalam hasil analisis diatas menunjukkan tingkat kerentanan yang berbeda-beda, baik setiap klasifikasi UMKM yang diteliti. Secara keseluruhan, kerentanan di setiap aspek UMKM pariwisata yang dijadikan sampel menghasilkan nilai "tinggi". Dari segi kerentanan ekonomi menunjukkan nilai 23 dengan metode likert yang berarti ada pada rentang yang "tinggi". Untuk kerentanan sosial menujukkan rentang "tinggi" dengan nilai 22. Juga untuk kerentanan fisik mempunyai hasil yang sama yaitu "tinggi" dengan nilai 22.

Dari segi kapasitas, ruang lingkup yang digunakan untuk matriks analisis diatas dibatasi dalam cakupan kesadaran pemilik atau pengelola UMKM pariwisata terhadap potensi bencana yang akan terjadi di masa yang akan datang. Hal ini terjadi karena kajian mengenai kapasitas di Indonesia hanya ada di tingkat daerah provinsi yang membutuhkan banyak variabel di dalamnya, sementara penelitian ini hanya sebatas UMKM pariwisata di wilayah kecamatan. Berdasarkan seluruh sampel penelitian, hasil menujukkan bahwa UMKM pariwisata di Kecamatan Lembang memiliki tingkat kapasitas yang sedang dengan nilai " 17 ".

Selanjutnya hasil di atas diolah menggunakan perhitungan analisis risiko UMKM pariwisata terhadap potensi bencana menggunakan metode likert. Hasilnya terdapat pada tabel 4 berikut :

Tabel 4 Hasil Analisis Risiko UMKM Pariwisata di Kecamatan Lembang

\begin{tabular}{ccc}
\hline $\begin{array}{c}\text { Tingkat } \\
\text { Risiko }\end{array}$ & $\begin{array}{c}\text { Klasifikasi } \\
\text { UMKM }\end{array}$ & Nama UMKM Pariwisata \\
\hline Tinggi & $\begin{array}{c}\text { Mikro, Kecil } \\
\text { dan } \\
\text { Menengah }\end{array}$ & $\begin{array}{c}\text { Nirwana Hotel, Mountain Spring,Pusat } \\
\text { oleh-oleh Kurnia Jati }\end{array}$ \\
\hline Sedang & - & - \\
\hline
\end{tabular}




\begin{tabular}{llc}
\hline Rendah & $\begin{array}{l}\text { Mikro dan } \\
\text { Menengah }\end{array}$ & $\begin{array}{l}\text { CV Dtrans Armada, Puri Saras } \\
\text { Garden, Sindang Reret, Hotel } \\
\text { Panorama dan Novena Hotel }\end{array}$ \\
\hline \multicolumn{2}{l}{ Sumber: Hasil Olah Data, 2019 }
\end{tabular}

Hasil tersebut menunjukkan bahwa risiko UMKM pariwisata di Kecamatan Lembang mempunyai tingkat risiko yang berbeda-beda tergantung jenis dan penghasilan UMKM tersebut. UMKM pariwisata yang memiliki hasil analisis risiko rendah mempunyai kesiapan mitigasi bencana yang terencana meskipun beberapa UMKM tersebut mempunyai tingkat kerentanan yang tinggi dari tiga aspek yang telah dikaji. Adanya prosedur mitigasi bencana, staff terlatih serta bangunan yang tahan bencana disebabkan UMKM pariwisata tersebut mempunyai aset serta penghasilan yang lebih tinggi dibandingkan UMKM pariwisata lainnya di Kecamatan Lembang. Sementara untuk UMKM pariwisata dengan hasil analisis risiko tinggi tidak mempunyai kesiapan mitigasi bencana yang terencana meskipun tingkat kerentanan pada tiga aspek yang dikaji pada UMKM tersebut tinggi.

Meskipun seluruh UMKM berada pada tingkat bahaya rendah karena berada di zona 1, akan tetapi hal itu tidak membuat UMKM berisiko rendah akan bencana. Hal ini terjadi karena untuk mengukur bahaya dalam penelitian ini menggunakan zonasi kerawanan bencana gunung api, sementara Lembang selain mempunyai potensi bencana gunung api juga memiliki potensi akan terjadinya sesar lembang yang bisa terjadi.

Hasil dari analisis ini juga menunjukkan bahwa konsep Prideux (2003) bahwa operator pariwisata tidak memperhatikan perencanaan bencana untuk menjadi bagian penting dari manajemen bisnis, terutama di daerah yang tidak memiliki sejarah bencana alam terkini, tidak berlaku pada setiap UMKM pariwisata. Pada kenyataanya, beberapa pelaku UMKM menganggap perencanaan bencana sudah menjadi sesuatu yang penting dalam bisnis mereka meskipun pada daerah yang belum mempunyai catatan sejarah bencana alam terkini. Dalam kasus ini, Sesar lembang dan erupsi gunung Tangkuban Parahu belum mencatatkan bencana yang sangat signifikan yang berdampak pada kehidupan manusia di sekitar Kecamatan Lembang.

\section{KESIMPULAN}

Dari hasil penelitian wawancara dengan 8 UMKM pariwisata di kecamatan Lembang dengan klasifikasi tiga jenis UMKM yang berbeda, yaitu Mikro, Kecil, dan Menengah, ditemukan bahwa seluruh UMKM mempunyai kesadaran akan potensi bencana pada tingkat sedang. Mayoritas UMKM yang mempunyai aset serta penghasilan yang lebih besar mempunyai persiapan yang lebih terencana untuk menghadapi bencana di masa yang akan datang. Sementara UMKM yang mempunyai tingkat penghasilan yang lebih kecil hanya sadar akan adanya potensi bencana. Dari sisi kerentanan bencana yang meliputi aspek ekonomi, sosial, dan fisik, seluruh UMKM pariwisata yang diteliti mempunyai tingkat kerentanan yang tinggi terhadap bencana. Sementara tingkatan risiko UMKM pariwisata menunjukkan bahwa UMKM skala mikro, kecil dan menengah memiliki risiko tinggi, dan sebagain UMKM skala mikro dan menengah memiliki risiko rendah. Dengan demikian, apabila semakin besar skala usahanya, semakin tinggi pula tingkat kesadaran pengelola dalam menghindari risiko bencana alam. Penelitian ini juga memiliki manfaat praktis bagi seluruh stakeholders disekitar wilayah rawan bencana alam. Pentingnya pemerintah daerah dan badan pengelola bencana untuk melakukan edukasi dan sosialisasi secara berkelanjutan mengenai pentingnya mitigasi bencana bagi usaha pariwisata. Selain itu, penting dilakukan pengawasan tata ruang, pengecekan standar kelayakan bangunan dari aspek konstruksi dan struktur untuk mencegah dan mengurangi dampak yang ditimbulkan akibat aktivitas gunung api atau gempa bumi.

\section{DAFTAR PUSTAKA}

Becken, S. (2004). The tourism disaster vulnerability framework:. Nat Hazards, 955-972. 
Becken, S. Kennet F.D Hughey (2013). Linking Tourism Into Emergency Management Structures To Enhance Disaster Risk Reduction. Tourism Management, 77-85

Biggs. (2011). Understanding resilience in a vulnerable industry: The case of reef tourism in Australia. Ecology and Society, 1-30.

Biggs, D. B. (2012). Lifestyle values, resilience and nature-based tourism's contribution to conservation on Australia's Great Barrier Reef. Environmental Conservation.

Carpenter. (2005). Surrogates for resilience of social-ecological systems. Ecosystems, 941-944.

Cioccio, L. \&. (2007). Hazard or disaster: Tourism management for the inevitable in Northeast Victoria. Tourism Management, 1-11.

Drabek. (1994). Risk perceptions of tourist business managers. Environmental Professional, 327-341.

Faulkner, B. (2001). Towards a framework for tourism disaster management. Tourism Management.

Gatra.com (2019, 9 Juni). Disparbud Jabar Catat Kenaikan Wisatawan Di Bandung Raya. Diakses Pada 2 Juli 2020, dari gatra.com/news/42065

Hidayat, E. (2010). Analisis Morfotektonik Sesar Lembang, Jawa Barat. Balai Informasi dan Konservasi Kebumian LIPI.

Huan, T.-C. (2004). NO-ESCAPE NATURAL DISASTER. Annals of Tourism Research, 255-273.

Huang, Y.-C. (2008). Crisis Management Planning to Restore Tourism After. Journal of Travel \& Tourism Marketing, 203-221.

Huang, Y.-C. T.-P. (2007). Crisis management planning to restore tourism after. Journal of Travel and Tourism Marketing, 23(2), 203-221.

Hystad, P. \&. (2008). Towards a destination tourism disaster management framework: Long-term lessons from a forest fire disaster. Tourism Management, 151-162.

Jones, L. \&. (2011). Preparing for the 'Big One': The great Southern Californian shake out. Earthquake Spectra, 575595.

Johnston, D.M., Bebbington Chin-Diew Lai, M.S., Houghton, B.F. and Paton, D. (1999), "Volcanic hazard perceptions: comparative shifts in knowledge and risk", Disaster Prevention and Management, Vol. 8 No. 2, pp. 118-126. https://doi.org/10.1108/0965356991026 6166

KPMG (2016). Preparing MSMEs for effective disaster management, 16

McCahon, I. D. (2006). Alpine fault earthquake scenario. West Coast Engineering Lifelines Study.

Nelson, D. A. (2007). . Adaptation to environmental change: Contributions of a resilience framework. Annual Review of Environment and Resources, 395419.

Orchiston, C. (2012). Tourism business preparedness,resilience and disaster planning in a region of high seismic risk: the case of the Southern Alps, New Zealand. Current Issues in Tourism, 477-494.

Paton, D. \&. (2006). Disaster resilience: An integrated approach. . Springfield, Illinois: Charles C. Thomas Publisher Ltd.

Pemerintah Indonesia. 2008. Undang-Undang Nomor 20 Tahun 2008 Yang Mengatur Usaha Mikro Kecil dan Menengah. Lembaran Negara RI tahun 2008. Sekretariat Negara, Jakarta

Pemerintah Indonesia. 2008. Undang-Undang Nomor 24 Tahun 2007 Yang Mengatur Tentang Penanggulangan Bencana. Lembaran Negara RI tahun 2008. Sekretariat Negara, Jakarta

Pforr. (2009). Crisis management in tourism: A review of emergency literature. Crisis management in the tourism industry: Beating the odds?,, 37-62. 
Prideaux. (2003). Journal of Travel and Tourism Marketing, 15(4), 281- 298.

Rahmafitria, F \& G.R Nurazizah. Community Based Tourism : A Corelation Between Knowledge And Pariticipation In Mountain Based Destination, 1st UPI International Conference on Sociology Education (UPI ICSE 2015), 80-83

Rahmafitria \& Misran (2018). Disaster risk and travel decision of Middle Eastern tourists to natural destination in Indonesia. IOP Conference Series: Earth and Environmental Science, Volume 179, Issue 1, pp. 012006 (2018). HYPERLINK "https://ui.adsabs.harvard.edu/link_gate way/2018E\&ES..179a2006R/doi:10.10 88/1755-1315/179/1/012006" It "_blank" $\underline{10.1088 / 1755-}$ $1315 / 179 / 1 / 012006$

Ritchie. (2009). Crisis and disaster management for tourism. Bristol, $U K$ : Channel View Publications.

Ritchie, B. (2008). Tourism Disaster Planning and Management: From Response and. Current Issues in Tourism, 315-348.

Ritchie, B. B. (2011). Proactive crisis planning: Lessons from the accommodation industry. ,. Scandinavian Journal of Hospitality and Tourism, 367-386.

Seville, E. B. (2006). Building organisational resilience: A summary of key research findings. Christchurch: Resilient Organisations Programme, University of Canterbury.

Sugiyono. 2012. Memahami Penelitian Kualitatif. Bandung : ALFABETA

Tirto.id. (2017, 20 Oktober). Sesar Lembang Mengintai Bandung. Diakses Pada 27 Juli 2019, dari HYPERLINK "https://tirto.id/gempa-besar-di-sesarlembang-mengintai-bandung-cyE3" https://tirto.id/gempa-besar-di-sesarlembang-mengintai-bandung-cyE3

Tim Penyususun. 2015. Buku Risiko Bencana Indonesia. Jakarta : BNPB

Wang, R. \&. (2010). A theoretical model form strategic crisis planning: Factors influencing crisis planning in the hotel industry. International Journal of Tourism Policy, 297-317.

Webb, G.R., Tierney, K.J., \& Dahlhamer, J.M. (2002). Predicting long-term business recovery from disaster: A comparison of the Loma Prieta earthquake and Hurricane Andrew. Environmental Hazards, 4, 45- 58.

Yuliani, L., Kastolani, W., \& Rahmafitria, F. (2018). Analisis persepsi wisatawan nusantara dan wisatawan mancanegara mengenai mitigasi bencana dan minat berkunjung di TWA gunung Tangkuban Parahu. Journal of Indonesian Tourism, Hospitality and Recreation, 1(1), 58-68. 